|| ISSN(online): 2589-8698 || ISSN(print): 2589-868X || International Journal of Medical and Biomedical Studies

Available Online atwww.ijmbs.info

PubMed (National Library of Medicine ID: 101738825)

Index Copernicus Value 2018: 75.71

Original Research Article

Volume 3, Issue 7; July: 2019; Page No. 263-264

\title{
OSTEOPIOKILOSIS WITH EPISODIC SYMPTOMS
}

Dr. Surjeet Singh ${ }^{1}$, Dr. Punit Katoch ${ }^{2}$

${ }^{1,2}$ Department of Orthopaedics, Dr Rajendra Parsad Government Medical College, Kangra at Tanda, Himachal Pradesh

Article Info: Received 28 June 2019; Accepted 27 July. 2019

DOI: https://doi.org/10.32553/ijmbs.v3i7.425

Address for Correspondence: Dr. Punit Katoch

Conflict of interest: Nil

\section{Abstract}

Osteopiokilosis is benign skeletal dysplasia diagnosed incidently as multiple oval sclerotic lesions of bone. We present a case report of 57 years male with episodic pain, swelling and superficial wounds of left knee from past 2 years. Osteopiokilosis have multiple periarticular osteosclerotic lesions which are mostly asymmetrical usually in long tubular bones and hands. To report episodic symptoms in osteopiokilosis and to avoid unnecessary panic of the patient after osteosclerotic lesion.

Keywords: Osteopiokilosis, osteosclerosis

\section{INTRODUCTION}

Osteopiokilosis is a rare benign skeletal dysplasia occouring in children but accidently discovered in adults usually presented with unrelated ailments. The incidence of the disease is 1:50000, which occour in both forms, inherited autosomal dominant and sporadically. Genetically it is due to mutation of LEMD3 gene at position 12q13, which is one of the gene required for mesenchymal tissue development ${ }^{1}$. It generally manifested as multiple sclerotic bony lesions of capal, tarsal, metaphysis and epiphysis of long bones, mostly sparing skull, ribs and clavicle $^{2}$. It is asymptomatic but $20 \%$ of patients may present with generalized bodyache, joint pain or joint effusion.

\section{Clinical Case}

A 57 years male presented to us, refered from peripheral institute where he was receiving treatment in form of antibiotics and analgaesics for wounds over left knee. As per patient history he was had 3-4 episodes of pain, swelling and wounds on left knee from past 2 years. Each episode lasting for 2-3 weeks and in between the patient was asymptomatic. Patient was smoker and chronic alcohalic from more than 10 years. On examination overlying skin showed healed and crusted wounds with no active discharge. Local temperature not raised. No joint effusion or muscle wasting around the joint was noted. Range of motion of both knee joint found to be equal and normal.

Patient initially viewed and worked as case of subacute infection of knee and was subjected for routine investigation like Haemoglobin 12gram, Total leukocyte count 9400(Neutroplil 58\%, Lymphocyte $38 \%$, Monocyte 02\%, Eosinophil 02\%), Erythrocyte sedimentation rate $06 \mathrm{~mm}$ in first hour. Fasting blood sugar $75 \mathrm{mg} / \mathrm{dl}$, serum uric acid $5.0 \mathrm{mg} / \mathrm{dl}$, serum alkaline 65 . X-rays of chest appears to be normal . All initial investigation comes out to be normal except $X$ ray of the knee which showed multiple well defined periarticular sclerotic bony lesions with maintained articular surface.Initial diagnosis was relooked again and patient was again subjected to $x$-rays of right knee(Figure-2) and both hands(Figure-1) and multiple well defined periarticular sclerotic bony lesions with maintained articular surface were found hence the diagnosis of Osteopiokilosis was given. 


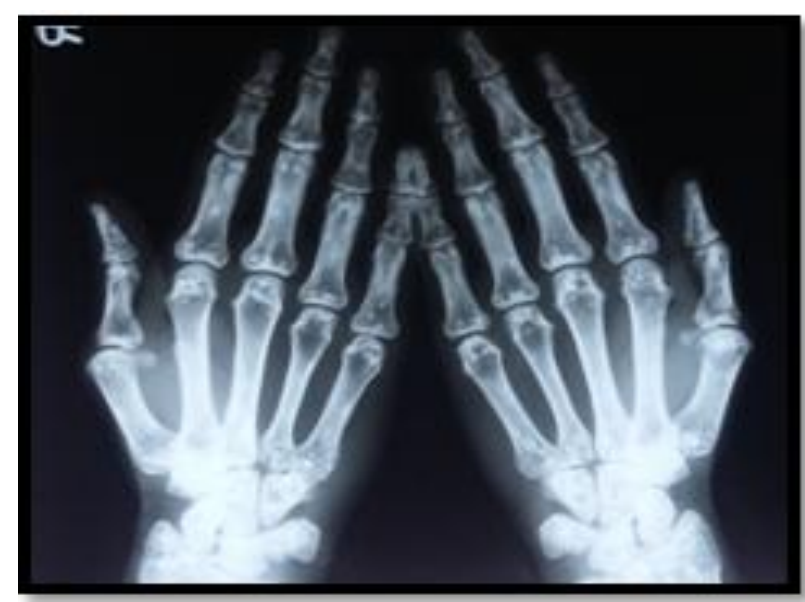

Figure 1: X-ray of both hand showing multiple oval sclerotic lesions.

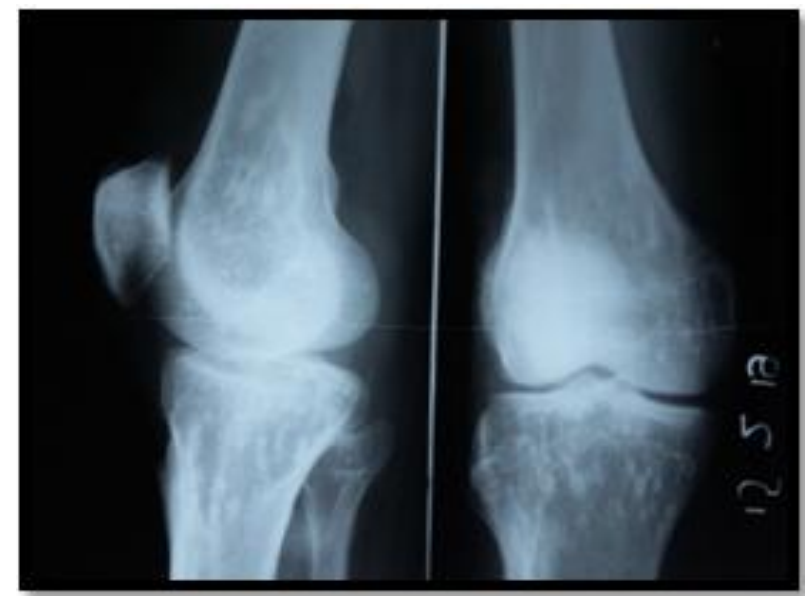

Figure 2: X-ray of right knee with periarticular sclerotic lesions.

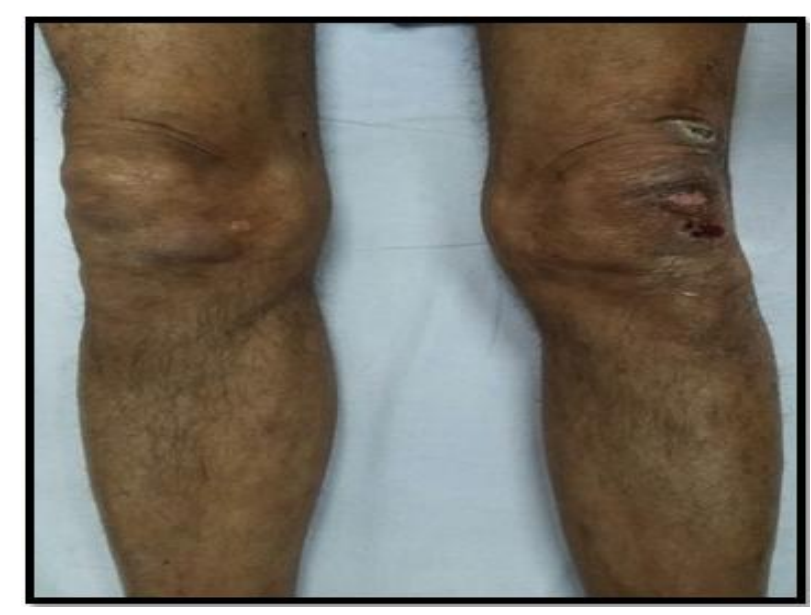

Figure 3: Both knees of patient of osteopiokilosis

\section{Discussion}

Osteopiokilosis is although a benign condition and $x-$ ray findings are typically oval shaped, symmetrical along the major trabeculaes mostly in epiphyseal and metaphyseal region. But majority of times its a incidental finding in a patient presented for other illness as of our case. It is mimicked by Osteoblastic metastasis, Mastocytosis, Osteoscleriotic myeloma, Tuberous sclerosis and Metabolic osteopathies ${ }^{3}$. In these conditions lesions are asymmetrical,mostly axial with bone destruction and periosteal reaction and active on bone scintography ${ }^{4}$.Skeletal disorders ${ }^{5}$, syndactyly, cleft palate, heart or renal malformations, and endocrine and autoimmune disorders ${ }^{6}$ have also been reported in association with osteopoikilosis.

\section{Conclusion}

The purpose of reporting this case is to present episodic symptoms of the disease and to high light the need to avoid panic to patient who is otherwise normal. Invasive and expensive investigation can be used judiciously to make diagnosis of osteopiokilosis.

\section{References}

1. Gutierrez D, CooperKD, Mitchell AL, Cohn HI. Novel somaticmutation in LEMD3 splice site results in Buschke-Ollendorff syndrome with polyostotic melorheostosis and osteopoikilosis. Pediatr Dermatol 2015;32:e219-20.

2. Benli IT, Akalyn S, Boysan E, Mumcu EF, Kis M, Turkoglu D. Epidemiological, clinical and radiological aspects of osteopoikilosis. J Bone Joint Surg $\mathrm{Br}$ 1992;74:504-6.

3. Resnick D, Niwayama G. Enostosis, hyperostosis and periostitis. In: Reznick D, Niwayama G, editors. Diagnosis of Bone and Joint Disorders. Philadelphia: W.B. Saunders Company; 1988;4084.

4. Woyciechowsky TG, Monticielo MR, Keiserman B, Monticielo OA. Osteopoikilosis: what does the rheumatologist must know about it? Clin Rheumatol 2012;31:745-8.

5. Weisz GM. Lumbar spinal canal stenosis in osteopoikilosis. Clin Orthop Relat Res 1982;89-92.

6. Woyciechowsky TG, Monticielo MR, Keiserman B, Monticielo OA. Osteopoikilosis: what does the rheumatologist must know about it? Clin Rheumatol 2012;31:745-8. 